\title{
IDENTIFIKASI TELUR NEMATODA USUS PADA KOL (Brassica oleraceae) DI PASAR TRADISIONAL KOTA MAKASSAR
}

\author{
Widarti \\ Jurusan Analis Kesehatan Poltekkes Makassar \\ widarti@poltekkes-mks.ac.id
}

\begin{abstract}
ABSTRAK
Sayur kol merupakan salah satu pendamping makanan pokok yang kaya gizi. di dalam sayuran terkandung protein, vitamin dan mineral.Sebagai sayuran, Kol banyak mengandung vitamin dan mineral yang sangat di butuhkan tubuh manusia. Juga dapat membantu pencernaan, menetralkan zat-zat asam dan memperlancar buang air besar. Kubis atau kol di konsumsi sebagai sayuran daun, di antaranya sebagai lalapan (lalap) mentah dan di masak, lodeh, campuran bakmi, lotek, pecal, asinan dan aneka makanan lainnya. cacing usus dapat di tularkan melalui tanah (soil transmitted helmint). penelitian ini bertujuan untuk mengetahui ada tidaknya telur nematoda usus pada sayur kol yang di pasar tradisional Kota Makassar.Penelitian ini bersifat observasi laboratorik,diambil 10 sampel kol secara purposive sampling selanjutnya di lakukan identifikasi dengan metode flotasi.dari hasil identifikasi menunjukkan bahwa tidak di temukan telur nematoda usus pada kol yang diperjualbelikan di pasar tradisional kota Makassar. Disarankan perlu dilakukan penyuluhan kepada pedagang sayur mengenai kontaminasi telur nematoda usus pada sayuran sehingga tingkat hygiene tetap terjaga.
\end{abstract}

Kata kunci : Kol, Nematoda usus

\section{PENDAHULUAN}

Jumlah infeksi kecacingan yang sangat banyak di Asia Tenggara termasuk Indonesia, dipengaruhi oleh kondisi iklim yang sesuai untuk pertumbuhannya, kondisi sanitasi lingkungan dan higiene perorangan yang buruk serta keadaan sosial ekonomi dan pendidikan yang rendah. (Kundain, 2012)

Di Indonesia angka kesakitan karena terinfeksi cacing usus atau perut cukup tinggi. Hal ini dikarenakan letak geografis Indonesia didaerah tropis yang mempunyai iklim yang panas akan tetapi lembab. Pada lingkungan yang memungkinkan, cacing usus dapat berkembang biak dengan baik terutama oleh cacing yang ditularkan melalui tanah (Soil transmitted Helminth). Penularan cacing usus bisa terjadi melalui makanan atau minuman atau secara langsung melalui tangan yang tercemar telur cacing yang infektif. (Muyassaroh, 2006)

Masyarakat Indonesia mempunyai kebiasaan memakan sayuran dalam bentuk lalapan untuk campuran makanan lain. Kebiasaan memakan sayuran mentah perlu hatihati terutama jika dalam pencucian kurang baik sehingga memungkinkan masih adanya telur cacing padasayuran. Parasit pada sayuran 
yang biasanya ditemukan adalah Ascaris lumbricuides, Trichuris trichiura, cacing tambang, larva Strongyloides stercoralis, larva Rhabditidae dan cercaria yang umumnya di tularkan melalui makanan/minuman atau melalui kulit. (Khomsan, 2005)

Sayuran merupakan makanan pendamping makanan pokok yang kaya gizi. Di dalam sayuran terkandung protein, vitamin dan mineral. Hampir semua jenis vitamin dan mikronutrien (terutama mineral) yang penting bagi tubuh terdapat pada sayuran,salah satunya adalah sayur kol. Selain vitamin dan mineral, memiliki kandungan serat yang tinggi.

Sebagai sayuran, Kol banyak mengandung vitamin dan mineral yang sangat di butuhkan tubuh manusia. Sebagai sayuran, kubis dapat membantu pencernaan, menetralkan zat-zat asam dan memperlancar buang air besar. Kubis atau kol di konsumsi sebagai sayuran daun, di antaranya sebagai lalapan (lalap) mentah dan masak, lodeh, campuran bakmi, lotek, pecal, asinan dan aneka makanan lainnya.

Sayur kol yang di cuci bersih kemungkinan besar masih mengandung telur cacing. Penggunaan sayuran mentah yang langsung dikonsumsi dimungkinkan masih tercemar oleh kotoran. Penyebaran cacing usus pada makanan sayuran dapat terjadi tingkat konsumen. Prevalensi penyakit cacing yang di tularkan melalui tanah di daerah tropik masih cukup tinggi. Beberapa spesies dari nematoda hidup sebagai parasit didalam saluran pencernaan tubuh manusia, dan didalam suatu kasus tertentu kemungkinan juga dapat ditemukan pada faeces (kotoran) manusia. Manusia merupakan hospes beberapa nematoda usus. Sebagian besar Nematoda ini menyebabkan masalah kesehatan masyarakat di Indonesia. Diantara Nematoda usus terdapat sejumlah spesies yang ditularkan melalui tanah dan disebut - soil transmitted helminthes yang terpenting bagi manusia adalah Ascaris lumbricoides, Necator americanus, Ancylostoma duodenale, Trichuris trichiura, Strongyloides stercolaris dan beberapa spesies Trichostrongylus. Nematoda usus lainnya yang penting bagi manusia adalah Oxyuris vermicularis dan Trichinella spiralis. (Nugroho dkk, 2010)

Berdasarkan latar belakang di atas, penulis telah melakukan penelitian identifikasi telur Nematoda usus pada sayur kol di Pasar Tradisional Kota Makassar

\section{METODE}

Jenis penelitian ini yaitu observasi laboratorik yang bersifat deskriptif untuk mengetahui gambaran hasil pemeriksaan telur nematoda usus pada kol di pasar tradisional Kota Makassar.

Lokasi pengambilan sampel adalah dibeberapa pasar tradisional di Kota Makassar. Lokasi pemeriksaan dilaksanakan di Laboratorium Parasitologi Jurusan Analis Kesehatan Politeknik Kesehatan pada tanggal 15 bulan Juni 2017.

Sampel yang di ambil dalam penelitian ini adalah sayur kol dari pasar tradisional Kota Makassar sebanyak 10 sampel dengan tekhnik pengambilan purposive sampling yaitu tekhnik pengambilan sampel yang di lakukan secara sengaja sesuai kriteria. 
Kriteria sampel penelitian yaitu: tempat penjualan yang terbuka, lingkungan sekitar penjualan yang kurang bersih dan kol yang masih segar.

Bahan penelitian yaitu sampel kol yang akan di periksa, aquadest, $\mathrm{NaCl}$ jenuh. Instrumen yang digunakan dalam penelitian ini yaitu gelas ukur $500 \mathrm{ml}$, rak tabung reaksi, tabung reaksi,mikroskop, pisau ,pipet tetes, Beaker glass, obyek glass, stopwatch dan cover glass.

Prosedur Penelitian

\section{Metode}

Metode yang di gunakan adalah flotasi yaitu menggunakan larutan $\mathrm{NaCl}$ jenuh yang di dasarkan atas berat jenis telur sehingga telur akan mengapung dan dapat diamati.

2. Prosedur Kerja

a. Persiapan sampel

Membuat larutan $\mathrm{NaCl}$ menggunakan aquadest $500 \mathrm{ml}$ yang telah dicampur garam sedikit demi sedikit sampai garam tidak bisa larut. Sayuran yang telah disiapkan dipotong kecil-kecil.

b. Pemeriksaan mikroskopik
Dimasukkan larutan $\mathrm{NaCl}$ dan sayuran ke dalam beaker glass kemudian aduk 10-15 menit agar parasit yang ada di sayuran bisa tercampur dengan larutannya. Dimasukkan cairan pada tabung reaksi besar. Isi penuh sampai bibir tabung kemudian tutup dengan cover glass dan dibiarkan selama 60 menit. Angkat cover glass dan letakkan di atas obyek glass. Kemudian diperiksa dengan mikroskop mengunakan perbesaran 10x-40x

Analisa Data

Teknik analisa data diperoleh dari hasil pemeriksaan telur cacing nematoda usus yang di sajikan dalam bentuk tabel dan hasilnya dibahas dalam bentuk narasi.

\section{HASIL}

Berdasarkan hasil penelitian yang dilakukan di Laboratorium Parasitologi Jurusan Analis Kesehatan Politeknik Kesehatan Makassar pada tanggal 15 Juni 2017 terhadap kol (Brassica oleraceae) di pasar tradisional kota Makassar.di peroleh hasil sebagai berikut :

Tabel 1 Hasil Identifikasi Telur Nematoda Usus Pada Kol (Brassica oleraceae ) di Pasar Tradisional Kota Makassar

\begin{tabular}{|l|c|c|}
\hline No. & Kode sampel & $\begin{array}{c}\text { Hasil identifikasi telur nematode usus } \\
\text { pada kol (Brassica oleraceae) }\end{array}$ \\
\hline 1 & A & Negatif (-) \\
\hline 2 & B & Negatif (-) \\
\hline 3 & C & Negatif (-) \\
\hline 4 & D & Negatif (-) \\
\hline 5 & E & Negatif (-) \\
\hline 6 & F & Negatif (-) \\
\hline 7 & G & Negatif (-) \\
\hline 8 & H & Negatif (-) \\
\hline 9 & I & Negatif (-) \\
\hline 10 & J & \\
\hline
\end{tabular}


Pada tabel 1 di atas hasil pemeriksaan telur nematoda usus pada 10 sampel kol (Brassica oleraceae) tersebut menunjukkan bahwa semua sampel kol negatif atau tidak ditemukan adanya kontaminasi telur nematode usus.

\section{PEMBAHASAN}

Sayuran merupakan makanan pendamping makanan pokok yang kaya gizi. Di dalam sayuran terkandung protein, vitamin dan mineral. Hampir semua jenis vitamin dan mikronutrien (terutama mineral) yang penting bagitu pun terdapat pada sayuran, salah satunya adalah sayur kol. Selain vitamin dan mineral, memiliki kandungan serat yang tinggi.

Sebagai sayuran, Kol banyak mengandung vitamin dan mineral yang sangat dibutuhkan tubuh manusia. Sebagai sayuran, kubis dapat membantu pencernaan, menetralkan zat-zat asam dan memperlancar buang air besar. Kubis atau kol di konsumsi sebagai sayuran daun, diantaranya sebagai lalapan (lalap) mentah dan masak, lodeh, campuran bakmi, lotek, pecal, asinan dan aneka makanan lainnya.

Hasil penelitian yang di lakukan oleh Bieer pada tahun 1991,mengenai isolasi pada sayuran dan buah-buahan menggunakan metode infitro diantaranya di gunakan sayur kol sebagai contoh uji pemeriksaan di dapatkan gambaran adanya kontaminasi spesies telur ascaris sp dan trichuris $\mathrm{sp}$ dalam bentuk telur dekortikasi dengan rata ratapertumbuhan $10 \%$ daritelur yang dibiakkan.

Berdasarkan hasil penelitian Sayur kol yang di perjualbelikan di pasar tradisonal Kota Makassar menunjukkan bahwa sayur kol dari pasar Pa'baeng-baeng, pasar Tidung, pasar Maricayya, pasar Hertasning, pasar Dg tata, pasar Manuruki, pasar Pettarani, pasar Terong, pasar Senggol, dan pasar Rajawali tidak ditemukan telur nematode usus pada sayur kol tersebut sehingga aman untuk di konsumsi masyarakat ini bisa di karenakan bahwa distribusi dari penjualan tersebut memiliki tingkat hygiene yang cukup baik. Beberapa factor yang berpengaruh terhadap kebersihan dalam pengolahan dan pemanfaatan sayuran yang diperjualbelikan di pasar tradisional kota Makassar seperti cara mencuci sayuran atau penggunaan air mengalir lebih di anjurkan dari pada menggunakan air yang tergenang.

\section{KESIMPULAN}

Berdasarkan hasil penelitian yang dilakukan di Laboratorium Parasitilogi Jurusan Analis Kesehatan Poltekkes Makassar terhadap 10 sampel kol (Brassica oleraceae) di peroleh hasil Negatif atau tidak ditemukan adanya telur nematoda usus (Ascaris lumbricoides, Trichuris trichiura, Necator americanus, dan Ancylostoma duodenale)

\section{SARAN}

a. Perlu dilakukan penelitian selanjutnya pengenai pencemaran nematode usus pada kol dengan menggunakan metode yang berbeda.

b. Perlu dilakukan penyuluhan kepada pedagang sayur mengenai kontaminasi telur nematoda usus pada sayuran sehingga tingkat hygiene tetap terjaga . 


\section{DAFTAR PUSTAKA}

Al-Rasyid,M. 2012. Trichuris trichiura (Cacing Cambuk). http://maksumprocedure.blogsp ot.com/2012/05/trichuristrichiura-cacing cambuk.html?m=1. Diakses 7 April 2017

Ganda husada, Srisasi., Herry D., Wita Pribadi. 2004. Parasitologi kedokteran. Gaya baru.

Jefferey; Leach. 1983. Atlas Helmintologi dan protozoologi kedokteran. Edisi 2. Jakarta: Penerbit Buku Kedokteran EGC

Khomsan, Ali. Pencucian Sayuran. http://www.google.com. Di akses tanggal 7 April 2017

Kementerian Kesehatan RI. 2006. Keputusan Menteri Kesehatan Rupublik Indonesia Nomor 424/MENKES/SK/VI/2006

Tentang Pendoman Pengendalian Cacingan. Kementrian Kesehatan Republik Indonesia. Jakarta.

Kundain,F,. 2012. Hubungan Antara Sanitasi Lingkungan dengan Infestasi Cacing pada Murid Sekolah Dasar di Desa Teling Kecamatan Tombariri Kabupaten Minahasa. http://ejournal.unsrat.ac.id/ Diakses tanggal 8 April 2017

Levine, ND. 1990. Buku Pelajaran Parasitologi Veteriner. Gajah Mada University Press. Yogyakarta.

Nugroho C, Djanah SN, Mulasari SA. 2010. Identifikasi Kontaminasi
Telur Nematoda Usus pada Sayuran Kubis (Brassica oleracea) Warung Makan Lesehan Wonosari Gunung Kidul Yogyakarta Tahun 2010. Fakultas Kesehatan Masyarakat Universitas Ahmad Dahlan. Yogyakarta. (Online). Jurnal KESMAS UAD Vol 4, No 1. Diakses pada 8 April 2017.

Natadisastra djaenudin. 2009. Parasitologi Kedokteran. Jakarta: Penerbit Buku Kedokteran EGC

Peraturan Presiden No112 Tahun. 2007 tentang Penataan dan Pembinaan Pasar Tradisional, Pusat Perbelanjaan danToko Modern.

Soedarto. 2009. Pengobatan Penyakit Parasit Amubiasis Malaria Cacing Tambang Filariasis dan Penyakit Parasit lainnya. Sagung Seto. Jakarta

Suriptiastuti. 2006. Infeksisoiltransmittedhelminth:

Ascariasis, Trichiuriasis dan cacing tambang. Universa Medicina.

Siti Muyassaroh. 2006. Pengaruh Frekuensi Pencucian pada Daun Kubis (Brassica oleraceae Capitata) terhadap Jumlah Telur Cacing Usus (Nematoda Intestinalis). FKM UNIMUS. Semarang.

Wahyuningsih, Sri. 2011. Petunjuk Laporan Praktikum Parasitologi. Jember. 